\title{
Estela Campos e os momentos iniciais do abstracionismo no Pará (1957-1959): hipóteses sobre invisibilidades na história da arte
}

\author{
Estela Campos and early abstractionism in Pará (1957-1959): hypotheses on \\ invisibilities in art history
}

\author{
Gil Vieira Costa \\ Universidade Federal do Sul e Sudeste do Pará. Marabá, Pará, Brasil
}

\begin{abstract}
Resumo: Este artigo busca trazer informações sobre uma lacuna existente nos estudos historiográficos sobre arte em Belém, Brasil. Discute-se o papel da artista Estela Campos na consolidação das correntes abstracionistas no campo artístico desta cidade, analisando a recepção crítica de suas três primeiras exposições individuais (1957, 1958 e 1959, ocorridas nas cidades de Belém, Rio de Janeiro e Belém, respectivamente). São apresentadas as fontes, muitas das quais ainda inéditas ou pouco conhecidas, que permitem um esboço biográfico da artista. Da mesma maneira, são levantadas algumas hipóteses sobre aspectos (sexismo, provincianismo, abordagens historiográficas localistas) que teriam contribuído para sua invisibilidade na história da arte em Belém.
\end{abstract}

Palavras-chave: Estela Campos. Belém. Abstracionismo. História da arte. Arte brasileira.

\begin{abstract}
This paper presents information on a gap in the historiographic studies of art in Belém, Brazil. It discusses the role of the artist Estela Campos in the consolidation of abstractionist currents in the artistic field of Belém, analyzing critical reception of her first three solo exhibitions (1957, 1958 and 1959, in the cities of Belém, Rio de Janeiro, and Belém, respectively). Sources that provide a biographical sketch of the artist are presented, many still unpublished or barely known. In the same way, some hypotheses are raised about aspects that may have contributed to her invisibility in the art history of Belém (sexism, provincialism, localist historiographical approaches).
\end{abstract}

Keywords: Estela Campos. Belém. Abstractionism. Art history. Brazilian art.

VIEIRA COSTA, Gil. Estela Campos e os momentos iniciais do abstracionismo no Pará (1957-1959): hipóteses sobre invisibilidades na história da arte. Boletim do Museu Paraense Emílio Goeldi. Ciências Humanas, v. 13, n. 3, p. 699-717, set.-dez. 2018. DOI: http:// dx.doi.org/10.1590/1981.81222018000300012.

Autor para correspondência: Gil Vieira Costa. Universidade Federal do Sul e Sudeste do Pará. Avenida dos Ipês, s/n, ILLA, Cidade Universitária. Bairro Cidade Jardim. Marabá, PA, Brasil. CEP 68500-000 (gilvieiracosta@hotmail.com). ORCID: http://orcid.org/0000-0002-2893-7343. Recebido em 10/04/2018

Aprovado em 14/09/2018 


\section{CONSIDERAÇÕES INICIAIS}

A produção artística especializada chamada de 'abstracionista' (devido à sua ruptura com a representação figurativa) foi desenvolvida pelas vanguardas históricas na Europa, nas primeiras décadas do século 20. No Brasil, as visualidades geométricas há séculos faziam parte dos repertórios culturais indígenas (e de populações mestiças subalternizadas), mas, no campo das chamadas artes plásticas, houve resistência ao diálogo com aquelas correntes artísticas não figurativas europeias. Em geral, o modernismo artístico brasileiro esteve envolvido com a questão de uma 'identidade cultural' nacional (Couto, 2004), para a qual o tema (o país, suas paisagens naturais e culturais) era, portanto, imprescindível.

O debate público sobre o abstracionismo e suas vertentes - 'informalistas', 'tachistas', 'construtivistas', 'concretistas', 'neoconcretistas' - foi iniciado, no Brasil, ainda no final dos anos 1930 (Couto, 2004, p. 40-41), majoritariamente em tom de desconfiança e de recusa. Somente nos anos 1950 há a legitimação definitiva do abstracionismo no campo artístico nacional, com a produção e a defesa da arte concreta (que, inclusive, recusava para si o termo 'arte abstrata'), especialmente nas cidades do Rio de Janeiro e de São Paulo (Villas Bôas, 2014). Muitos outros centros brasileiros tiveram seus campos artísticos igualmente impactados pelas correntes abstracionistas - em um processo estimulado por circunstâncias de variados níveis de abrangência (local, nacional e internacional), que cabe estudar com maior rigor.

A questão que a princípio fomentou este artigo diz respeito aos momentos iniciais do abstracionismo no campo das artes plásticas em Belém, no estado do Pará. A respeito desse tema, a narrativa mais consagrada na historiografia local indica o papel de destaque do Clube de Artes Plásticas da Amazônia (CAPA), agremiação de artistas e de intelectuais que existiu em Belém desde o ano de 1959 aos anos iniciais da década de 1960 (Braga, 2003). Toma-se, em geral, as memórias de um dos membros do CAPA (José de Moraes Rego - Belém, Pará, 1926-1990 -, autor da dita primeira exposição abstracionista na cidade, em 1959) como ponto de partida.

Rego $(1979,1976)$ forneceu-nos duas narrativas que se complementam. Em um debate nos jornais (Rego, 1979), ele informou que teria sido outro artista local, Ruy Meira (Belém, Pará, 1921-1995), quem apresentara o abstracionismo ao CAPA e fomentara o projeto estético de guinada coletiva naquela direção. Três anos antes, uma matéria jornalística sobre sua segunda exposição individual indicou outro fator que agenciou seu interesse pelo abstracionismo: o contato com uma exposição de Stela Campos (sic) em Belém, “[...] na qual a artista fazia incursões no abstracionismo, embora associado ao figurativo, com formas de animais e pessoas monstruosas" (Rego, 1976, p. 4).

Ambas as matérias foram posteriormente republicadas em livro (Rego, 1986, p. 63-66 e p. 75-77), ganhando importância enquanto compilação de fontes sobre o assunto. Ainda que esta seja uma compilação sobre José Rego, e não propriamente sobre o abstracionismo em Belém, ela foi tomada por muitos dos trabalhos posteriores sobre este último tema. O estudo pioneiro de Acácio Sobral sobre o abstracionismo em Belém é um desses exemplos, sendo possível perceber as narrativas de José Rego (a relação 'Ruy Meira-Moraes Rego-Estela Campos') servindo de fonte para este estudo (Sobral, 2002, p. 51-52).

As matérias republicadas no livro de Rego (1986) também alimentaram as narrativas de Mokarzel (2000, p. 9) - que não chega a mencionar Estela Campos - e Braga (2003, p. 83-84). O livro de Sobral (2002), por sua vez, consolidou-se na restrita historiografia da arte local como uma pesquisa importante e obrigatória para os estudiosos do tema. Um relatório de Ricci ([1978], p. 306) também menciona a presença de Estela Campos em Belém, de modo mais completo do que José Rego, o qual, apesar de ainda inédito, influenciou a narrativa de Farias (2003, p. 109).

Em todo caso, a respeito de Ruy Meira, há um crescente número de estudos, assim como obras e documentação disponíveis em instituições públicas em Belém e em outras cidades brasileiras. $\bigcirc$ mesmo se pode

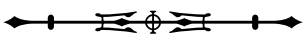


dizer sobre José Rego, ainda que seja menos estudado (e celebrado) do que Ruy Meira. Mas, ao buscarmos informações e obras de Estela Campos, o embaraço é inevitável, dada a ausência quase completa de fontes a respeito da artista.

De fato, no primeiro momento, Estela Campos me pareceu uma personagem não rastreável. Por outro lado, também me pareceu inconteste sua importância para as artes plásticas em Belém. Há algo de misterioso na invisibilidade dessa artista, lacuna histórica que inquieta e que urge confrontar.

\section{FONTES CONSULTADAS}

Em que pese a escassez de informações sobre a artista, é possível encontrar os rastros de sua produção em fontes primárias e secundárias, disponíveis em arquivos de instituições culturais. A lista que segue indica as fontes mapeadas até o momento e oferece um percurso bastante sólido para se aproximar da atuação artística de Estela Campos:

- Menção em catálogos de três edições da Bienal Internacional de São Paulo (Fundação Bienal de São Paulo, 1961, 1963, 1965);

- Verbete em quatro dicionários sobre artistas plásticos brasileiros (Pontual, 1969, p. 104; Cavalcanti, 1973, p. 333; Ayala, 1986, p. 166; Estela..., 2017);

- Participação nos campos artísticos em Belém e no Rio de Janeiro documentada nos jornais da época, disponíveis, respectivamente, na Biblioteca Pública Artur Viana (Fundação Cultural do Pará) e na Hemeroteca Digital Brasileira (FBN, 2017);

- Menção em pesquisa (inédita) sobre artes plásticas no Pará (Ricci, [1978], p. 306);

- Publicações literárias de sua autoria: além de textos publicados em jornais, também o livro "Kalta-ítsia", editado pela então Universidade do Pará (Campos, 1964);
- Coleção documental sobre a artista no Arquivo Histórico Wanda Svevo (AHWS), da Fundação Bienal de São Paulo.

Trato do conjunto destas fontes em outro texto (Vieira Costa, 2018). Aqui, retomarei especialmente aquelas relacionadas às três primeiras exposições individuais de Estela Campos, ocorridas antes da exposição de José Rego - tida como marco do abstracionismo em Belém. A partir dessas fontes, a atuação dessa personagem ganhou corpo para retomar a questão da arte abstrata na cidade e, obviamente, colocar novos problemas.

Cabe destacar a pasta 'Estela Campos' do AHWS, contendo correspondências entre a Bienal de São Paulo e a artista. Além das fichas de inscrição submetidas, há cartas, recortes de jornais, folhetos de exposições e, até mesmo, fotografias de obras' que, somadas aos registros publicados nos jornais, talvez constituam as únicas maneiras que dispomos para nos aproximar de sua produção - já que, até o momento, nenhuma obra da artista foi localizada.

A ausência ou a inexistência das obras de Estela Campos, hoje, mais do que constituir uma impossibilidade metodológica para a história da arte, indica uma condição muitas vezes presente nesse campo de estudos: a necessidade de se confrontar com obras mortas, desaparecidas, fragmentadas ou inexistentes, conceitualizadas como 'criptohistória de arte' por Serrão (2001). Ainda que o conjunto de registros de obras da artista seja diminuto, não são poucos os rastros deixados por sua atuação artística, como se pode perceber pelas fontes ora listadas.

Certamente, a inexistência ou a localização desconhecida das obras e a ausência de registros fotográficos consistentes impossibilitam uma análise formal da produção de Estela Campos - recurso que atestaria sua relevância estética, ao situá-la e compará-la em determinado contexto artístico. Se uma análise desse

1 Os recortes de jornais, os folhetos de exposição e as fotografias de obras foram, muito provavelmente, remetidos à Bienal pela própria artista, como dá a entender a carta de Estela Campos à Bienal de São Paulo, datada de 9 nov. 1963, p. 1. AHWS, Fundação Bienal de São Paulo, São Paulo.

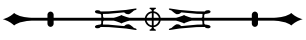


tipo não é viável, a relevância da produção da artista pode, ao menos, ser pressuposta pelo êxito que suas obras alcançaram, na época em que foram produzidas, no campo artístico de Belém, do Rio de Janeiro e de São Paulo, como se detalhará adiante.

Cabe ressaltar, ainda, que a análise formal das obras de Estela Campos não é a principal nem a única forma de compreender sua invisibilidade na historiografia sobre o abstracionismo em Belém. Decerto, como nos mostram os estudos de história social da arte, não há uma conexão determinista entre as características formais das obras e a sua fortuna crítica ou recepção social. A invisibilidade de Estela Campos nas narrativas historiográficas está condicionada por um emaranhado de fatores complexos, entre os quais figuram tanto as características estéticas das obras quanto as contingências sociais de um período e de um lugar.

Ainda que só nos restem os rastros dessa produção (de Estela Campos, como de outros artistas, decerto), é somente sua investigação que nos possibilita revisitar os momentos iniciais do abstracionismo em Belém. Cabe ao historiador trabalhar com interpretações dos vestígios desse processo histórico complexo, por mais esparsos que eles sejam. Confrontar essa 'memória diluída' de obras que não sobreviveram aos tempos é útil para estabelecer novos diálogos com as obras que, por seu turno, ainda fazem parte dos acervos públicos ou particulares. De acordo com as palavras de Serrão (2001, p. 13, grifos do autor):

[...] se os historiadores de arte esquecerem ainda mais as peças já de si inexoravelmente olvidadas de estrutura matérica, sem lhes buscarem devolver um possível halo de memória, estarão a truncar a reconstituição histórica de factos valiosos para uma abordagem em globalidade e, sobretudo, estão a privar a fortuna crítica de elementos de informação que podem ser poderosamente influentes, sobretudo quando o juízo crítico do historiador de arte se encontra (de)formado por uma selecção artificial, fortuita ou comprometida, quer de "obras de arte" quer de artistas.

\section{FORMAÇÃO INICIAL E PRIMEIRAS ATIVIDADES ARTÍSTICAS}

Maria Estela de Pinho Campos (Figura 1) nasceu no Rio de Janeiro, em 25 de abril de $1929^{2}$.

Cedo, migrou com a família para Portugal, onde realizou os estudos nos ensinos primário e secundário. Nesse período, teve seus primeiros contatos com práticas artísticas, participando de exposição escolar e, mais tarde, recebendo aulas particulares de desenho, com professor vinculado à Escola de Belas Artes do Porto. Retornou, então, ao Rio de Janeiro, e de lá seguiu para Belém. Nessa cidade, graduou-se Bacharel pela Faculdade de Direito

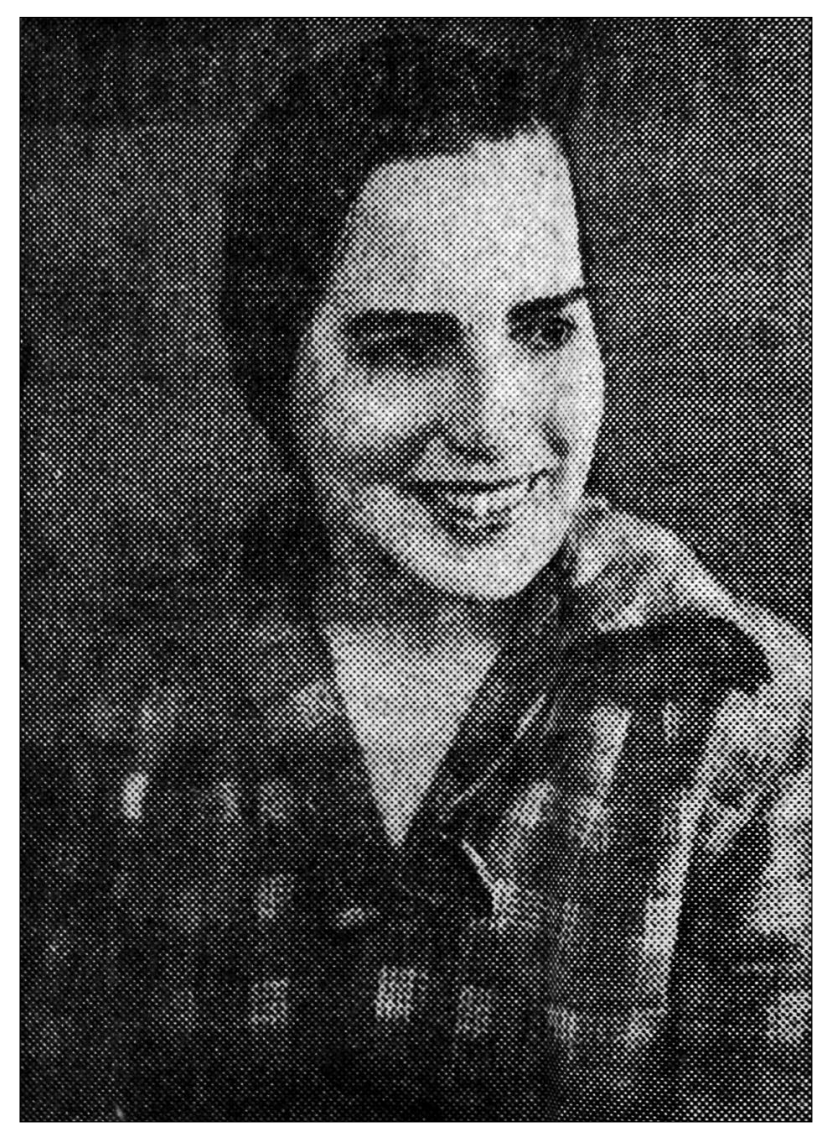

Figura 1. Estela Campos em foto publicada pelo jornal carioca Correio da Manhã. Fonte: Maurício (1960, p. 2).

2 Conforme consta em suas fichas de inscrição submetidas às três edições da Bienal de São Paulo em que participou. AHWS, Fundação Bienal de São Paulo, São Paulo.

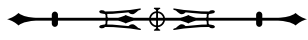


da Universidade do Pará. Transferiu-se para Lisboa em 1948, onde se deu parte importante de sua formação artística, tendo estudado pintura (com Almada Negreiros - Trindade, atual São Tomé e Príncipe, 1893-Lisboa, Portugal, 1970 - e Sarah Afonso - Lisboa, Portugal, 18991983), cerâmica (com João Fragoso - Caldas da Rainha, Portugal, 1913-Lisboa, Portugal, 2000) e desenho (com Martins Correia - Golegã, Portugal, 1910-1999). Durante esse período, viajou pela França e pela Espanha, visitando museus. Em 1949, expôs no II Salão de Cerâmica Moderna - Serviço Nacional de Informação, Cultura Popular e Turismo (SNI), de Portugal. Retornou a Belém no começo dos anos 1950, suspendendo parcialmente suas atividades artísticas para se dedicar à advocacia ${ }^{3}$.

Não se sabe a data exata de seu retorno à cidade. Em 1951 é certo que já se encontrava em Belém, tendo realizado viagem por Rio de Janeiro e São Paulo, ocasião em que visitou a I Bienal de São Paulo ${ }^{4}$. Em 1953, submeteu obras para a II Bienal de São Paulo. As fichas de inscrição nos informam se tratarem de uma escultura (trabalhada diretamente sobre gesso) e quatro desenhos sobre cartão. As fichas estão datadas em 29 de abril de 1953, e o endereço da artista, localizado no Rio de Janeiro.

Quase quatro meses depois, uma matéria em jornal nos informa que Estela Campos se inscreveu por meio do Museu de Arte Moderna do Rio de Janeiro (MAM Rio) e dá a entender que há alguma irregularidade em sua inscrição, solicitando providências (II Bienal..., 1953). Fico em dúvida se a artista estabeleceu residência no Rio de Janeiro naquele decurso de tempo ou se ainda residia em Belém. De qualquer modo, não constando seu nome no catálogo da mostra, conclui-se que não tenha sido selecionada - o que pode ter motivado uma pausa em suas atividades artísticas.
Os indícios dessas atividades só reaparecerão em 1957, com sua primeira exposição individual, em Belém. Antes de adentrar neste assunto, porém, cabe abrir um parêntese a respeito de outra questão.

\section{CONFLITO DE FONTES}

Em sua ficha de inscrição na II Bienal... (1953), que atualmente está disponível no AHWS, o ano de nascimento de Estela Campos consta como 1923. Tal informação contrasta com suas fichas de inscrição na década posterior, que trazem o ano de 1929, data publicada nos catálogos das edições do evento - provavelmente servindo de base aos verbetes em dicionários e demais trabalhos que mencionam a artista. Os catálogos de suas exposições individuais não informam o ano de seu nascimento.

Qual será a data correta, e por que existe essa inconsistência? A artista teria alterado sua idade intencionalmente, visando parecer mais nova ou mais velha diante dos júris de seleção (ou por algum outro motivo que nos escapa)?

Sua formação em Direito pode ser um ponto de apoio para considerar a questão. Sabemos que ela realizou o curso em Belém nos anos 1940, e que depois retornou a Portugal em 1948, para um período de formação artística. Ou seja, ela possivelmente concluiu o bacharelado em 1947. Qual a duração do curso? Provavelmente cinco anos. Mas consideremos que Estela Campos o tenha realizado em quatro anos: do início de 1944 ao fim de 1947. Se tomarmos seu nascimento em 25 de abril de 1929, ela teria começado o bacharelado às vésperas de completar quinze anos. A informação é ainda mais surpreendente quando consideramos que ela teria repetido um ano dos estudos secundários, em sua mudança de Portugal para o Brasil ${ }^{5}$.

3 Para as informações deste parágrafo, conferir material de divulgação de três exposições individuais de Estela Campos, no Rio de Janeiro: Livraria São José, 1958; Salão de Arte da Assembleia Legislativa do Estado da Guanabara, 1960; e Galeria Macunaíma, 1962. AHWS, Fundação Bienal de São Paulo, São Paulo.

4 Material de divulgação da exposição individual de Estela Campos, Rio de Janeiro, Salão de Arte da Assembleia Legislativa do Estado da Guanabara, 1960. AHWS, Fundação Bienal de São Paulo, São Paulo.

5 Conferir material de divulgação de exposição de Estela Campos no Salão de Arte da Assembleia Legislativa do Estado da Guanabara, Rio de Janeiro, 1960. AHWS, Fundação Bienal de São Paulo, São Paulo.

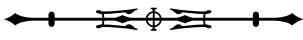


Comparemos sua cronologia com a de outro paraense notável, nascido em 1929 e egresso da mesma Faculdade de Direito da Universidade do Pará: Benedito Nunes (Belém, Pará, 1929-2011), que ingressou no curso apenas em 1947 e o concluiu em 1952 (Pinheiro, 2009). Assim, a trajetória da artista parece um tanto excepcional, se considerarmos seu nascimento em 1929. Entretanto, se considerarmos a data de 1923, Estela Campos teria ingressado na faculdade por volta dos 20 anos, e seguido para Lisboa, em 1948, com cerca de 25 anos - o que é bem mais plausível. A dúvida permanecerá posta até que novos documentos possam ser consultados, mas, no que diz respeito a uma hipótese pessoal, reformularei uma das frases desse artigo: Estela Campos nasceu em 25 de abril de 1923.

\section{PRIMEIRA EXPOSIÇÃO INDIVIDUAL}

Em 1957, Estela Campos realizou exposição individual em Belém, nos salões da Biblioteca e Arquivo Público do Estado do Pará, um dos espaços expositivos tradicionais à época. Calculada a partir dos dados disponíveis em jornal (A Biblioteca..., 1957; Frequência..., 1957), a média de público da biblioteca no período em que foi realizada a exposição (21 de agosto a 13 de setembro) foi de mais de mil e quinhentas visitações mensais, o que pode significar que a mostra tenha sido vista por amplos setores da sociedade belenense. Paolo Ricci (Lucca, Itália, 1925-Belém, Pará, 2011), artista ativo na cidade naquele momento, afirmará, duas décadas depois: "É significativa a sua exposição, pelos escândalos que causou, inclusive nos meios intelectuais. Classificada de 'onírica', Stella Campos [sic] exibiu desenhos de um surrealismo invadindo as raias do abstrato" (Ricci, [1978], p. 306).

O escândalo causado nos meios intelectuais pode ser interpretado como a resistência à estética modernista de Estela Campos, em um campo artístico dominado pelo conservadorismo de beletristas e de pintores de teor acadêmico. Não à toa, o que havia de mais experimental nas artes plásticas em Belém, na época, era a pintura de caráter pós-impressionista. E também não à toa, muitos desses pintores migraram para o abstracionismo de modo bastante paulatino e temeroso - por isso, teria cabido a José Rego, ainda que fosse o menos experiente, inaugurar o abstracionismo na cidade com sua exposição de 1959.

Apesar de polêmica, a exposição de José Rego não provocou a reação crítica que uma Anita Malfatti (São Paulo, São Paulo, 1889-1964) despertou na São Paulo de 1917. Quatro décadas depois das vanguardas históricas europeias, a atitude vanguardista parecia já estar despida de seu teor radical, para assumir um teor de erudição, mesmo em uma cidade à margem da arte internacionalizada, como Belém.

O que se percebe, pela documentação da época, é que a intelectualidade local via mesmo com bons olhos a iniciativa de José Rego, encarando a adesão ao abstracionismo como aspecto de modernização cultural local. Talvez a exposição de José Rego tenha sido bem recebida porque o caminho para o abstracionismo já havia sido pavimentado pelas exposições de Estela Campos, comentadas neste artigo, pela arquitetura modernista introduzida na cidade naquela década, entre outros aspectos.

Resta saber o que essa documentação revela sobre a recepção da mostra de Estela Campos. Curiosamente, diferentes jornais trazem notícias sobre uma exposição de pintura e de escultura de outra pessoa: Miranda Campos ${ }^{6}$. Os registros fotográficos publicados (Figura 2), além do sobrenome, indicam se tratar da mesma artista. Da mesma maneira, fotografias de duas obras datadas de 1957 (que talvez tenham feito parte da mostra), disponíveis no AHWS, são assinadas por E. Miranda Campos (Figura 3). O porquê da adoção desse codinome permanece sem resposta.

A mostra foi positivamente anunciada como a primeira exposição de arte abstrata na cidade (A Biblioteca..., 1957; Inaugurada..., 1957a). Diferente do 'escândalo' rememorado por Ricci ([1978]), os dois comentários críticos mais extensos nos jornais

\footnotetext{
6 Conferir, por exemplo: Exposição... (1957) e Uma exposição... (1957).
}

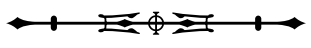




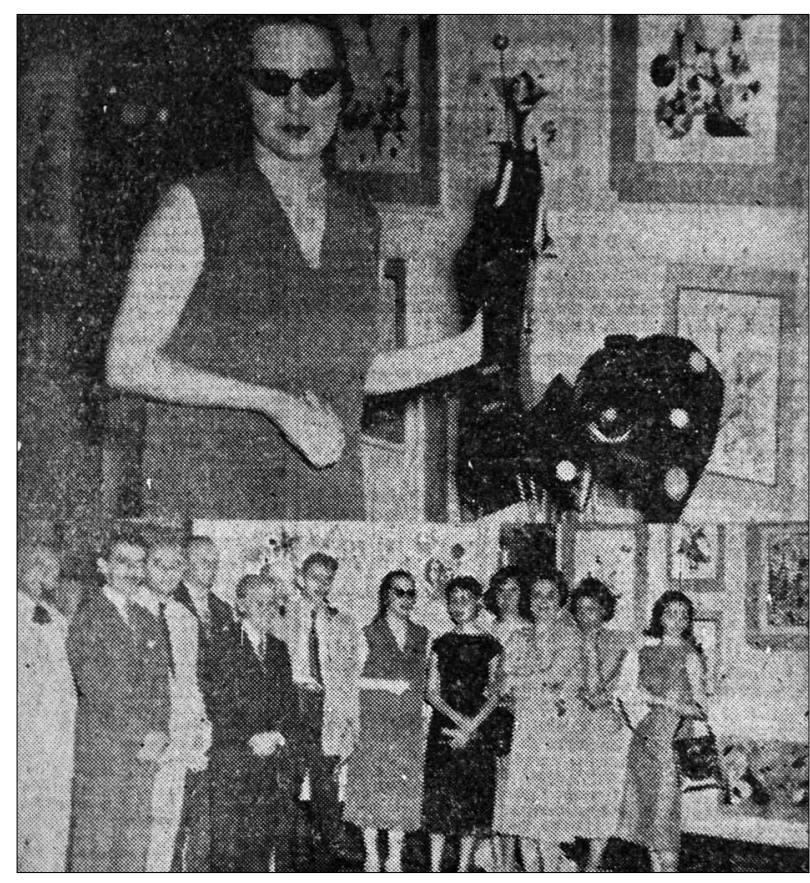

Figura 2. Registros da abertura da exposição de Miranda Campos, Biblioteca e Arquivo Público do Estado do Pará, Belém, 1957. Fonte: A Província do Pará (1957, p. 6).

são explicitamente favoráveis à mostra, ainda que um deles demonstre recear as controvérsias que a estética abstracionista poderia suscitar. Transcrevo a seguir um trecho significativo do referido comentário:

Dotada de excepcional talento e de sensibilidade, sente-se que a linguagem ultra-moderna em que se expressa a jovem expositora paraense não é fruto de uma improvisação mas, sim, da evolução natural de uma artista com base, que busca encontrar as soluções mais adequadas ao seu temperamento ou à sua compreensão estética. Por isso mesmo seus quadros e desenhos, bem como as suas esculturas, apesar da ausência que neles sente o espectador de todas as formas comuns, imitativas ou figurativas, impõem respeito, ainda que não os possamos entender de imediato por se desajustarem da nossa educação tradicional. Não raro inteiramente abstrata, dir-se-ia que buscando a harmonia só com movimentos geométricos e hábeis combinações de cores, vemo-la por vezes retornar ao figurativo, embora sempre dentro da mesma linha interpretativa. Naturalmente, não caberia num simples registro como este, explicar ou debater a tendência abstracionista da pintura

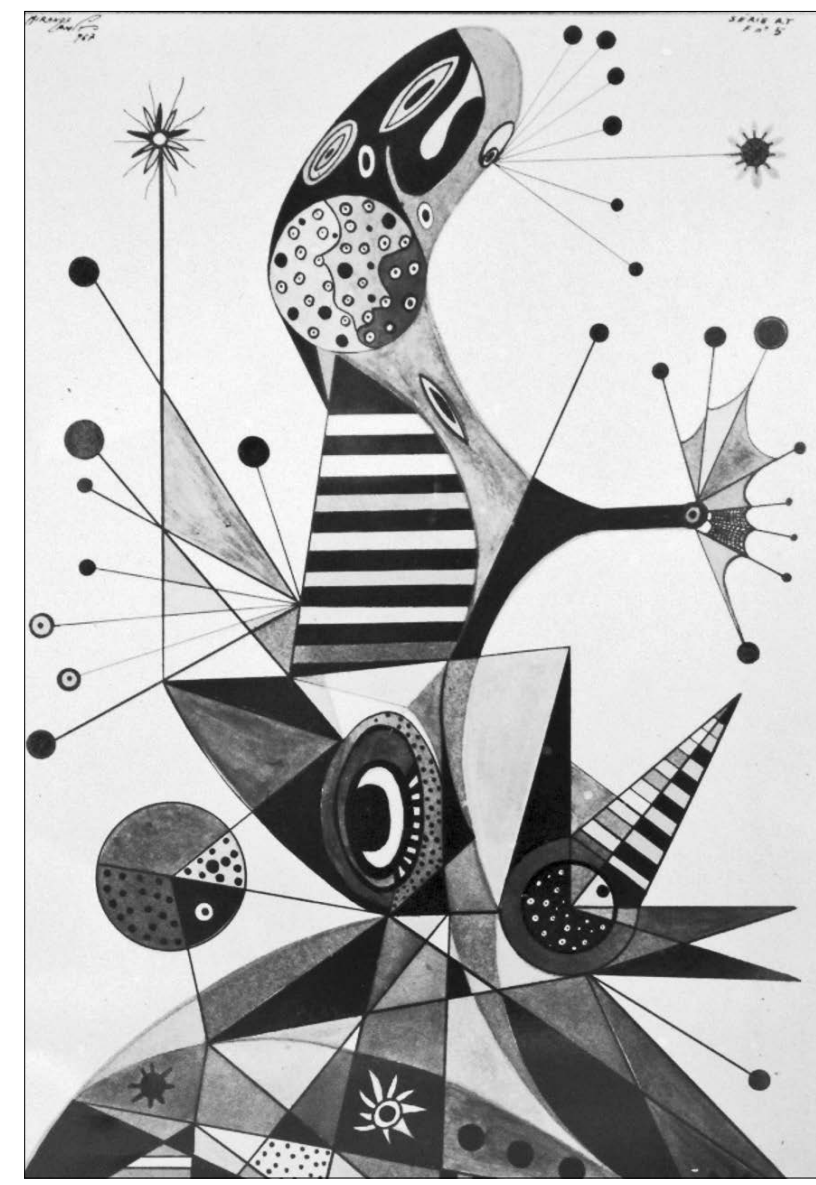

Figura 3. Registro da obra Figura n. 5, Série RT, Estela Campos (assinada como E. Miranda Campos), 1957. Fonte: pasta Estela Campos, AHWS, Fundação Bienal de São Paulo, São Paulo.

atual, à qual tão nitidamente se filia a pintora Miranda Campos. Em arte, todas as manifestações conscientes e honestas devem ser respeitadas, mesmo que não se casem com a nossa própria capacidade compreensiva ou emocional. E não há dúvida que na exposição ora franqueada ao público na Biblioteca Pública estamos diante de um conjunto com essas características. Daí vaticinarmos para a primeira mostra da talentosa pintora paraense um êxito certo que se traduzirá em muitos aplausos, mas, também e sobretudo, em muita discussão e controvérsia. (Inaugurada..., 1957a, p. 6).

Discussão e controvérsia não registradas em nenhuma documentação conhecida: o escândalo teria sido uma reação de bastidores, distante do debate público? De qualquer modo, aquilo que mais chama a atenção na

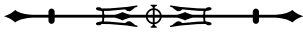


notícia é o fato de que boa parte da exposição é tomada como 'nitidamente abstracionista'. O outro comentário, assinado pelo intelectual Inocêncio Machado Coelho (Belém, Pará, 1909-2001), também não deixa dúvidas a respeito do abstracionismo praticado por Estela (Miranda) Campos, filiando-a aos europeus Georges Braque (França, 1882-1963) e Fernand Léger (França, 1881-1955). Seguem trechos do texto de Machado Coelho, que chega a assinalar um lugar de destaque para a exposição:

Dentro de seu "j'aime surtout la peinture", ele [Braque] se orientou para o "puro fato pictórico", ante do qual não devia e nem podia subsistir qualquer percepção a que se pudesse aliar uma lembrança. "Pensar na semelhança é pensar numa coisa falsa a priori", dizia em seu acento normando.

Pois bem, não fora Braque, seu amigo e companheiro, companheiro de "métier" e amigo de teto, creio que não teríamos Léger, a meu ver o verdadeiro criador da "arte abstrata", essa arte que se sente e não se explica, a arte da escultora e pintora Miranda Campos, com sua notável exposição na Biblioteca Pública.

[...] Escultora preocupada, apenas, com as contorções de suas figuras, inacabadas porque não começadas; pintora a quem só interessa o visual de suas composições - escultura e pintura uma dança viva de movimentos geométricos e combinações de cores - Miranda Campos realiza o milagre da criação artística sem fórmula nem definição.

Não tenho, assim, a menor dúvida em proclamar que sua exposição é a coisa mais séria que já se apresentou nesta terra, trazendo a marca do espírito de Léger e dentro do princípio de Braque: "Il n'est en art qu'une chose valable, celle que l'on ne peut expliquer".

Quem poderá explicar as magníficas, originais, violentas criações de Miranda Campos? Nem eu, decerto, nem ela, talvez [... ] (Coelho, I., 1957, p. 8).

\section{SEGUNDA EXPOSIÇÃO INDIVIDUAL}

Aparentemente, a primeira individual de Estela Campos não desagradou em nada a esfera governamental em Belém. Na verdade, parece mesmo ter ocorrido o inverso: sua mostra ter sido lida como bastante relevante. Isso explicaria o porquê de, em 1958, a artista ter viajado ao Rio de Janeiro, patrocinada pelo governo do Pará e pela Companhia Paraense de Transportes Aéreos (Campofiorito, 1958a), com o propósito de realizar exposição na (até então) capital do país.

Por conta das proporções do campo artístico e da imprensa no Rio de Janeiro, houve mais apreciação crítica da obra de Estela Campos nessa cidade do que em Belém. Porém, para além do patrocínio e da repercussão crítica positiva, esta segunda exposição individual de Estela Campos também enfrentou alguns empecilhos. A artista chegou ao Rio de Janeiro ainda em agosto de 1958, trazendo cerca de cento e setenta obras na bagagem (Bento, 1958). A realização de sua mostra, entretanto, esbarrou na indisponibilidade dos espaços expositivos da cidade (Moraes, 1958). Somente em 18 de setembro daquele ano, Estela Campos pôde apresentar sua exposição, ainda que de maneira um tanto prejudicada: o local que a acolheu foi uma livraria (e não um espaço expositivo especializado), houve lugar para apenas trinta obras (entre mais de uma centena das que trouxera de Belém) e a duração da mostra foi resumida a cinco dias, encerrada em 23 de setembro (Campofiorito, 1958c).

Ainda assim, pode-se dizer que Estela Campos não passou despercebida pela crítica carioca, tendo sido bem avaliada. A cobertura jornalística dada por Eneida de Moraes (Belém, Pará, 1904-Rio de Janeiro, Rio de Janeiro, 1971), Mário Barata (Leysin, Suíça, 1921-Rio de Janeiro, 2007) e Quirino Campofiorito (Belém, Pará, 1902-Niterói, Rio de Janeiro, 1993) parece natural, dadas as relações destes com Belém. Transcrevo, portanto, os principais trechos da crítica de um personagem a princípio mais neutro, Antônio Bento (Araruna, Paraíba, 1902-Rio de Janeiro, Rio de Janeiro, 1988):

Nas obras agora apresentadas, podem ser notadas duas fases diversas. A primeira abstrata, provindo da influência de Kandinsky. Mas, não se pense que a jovem paraense ficou presa ao mestre russo. Partiu apenas de algumas de suas composições para chegar a soluções pessoais, como as que se denominam "sistemas". As formas soltas de Kandinsky tomam aqui novo rumo, unem-se em constelações e em prismas, organizam-se segundo a lei que lhes dita a fantasia da artista.

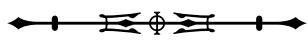


Nestes desenhos, Estela Campos consegue um equilíbrio maior, uma unidade visual de equilíbrio mais perfeito.

Na segunda fase, a artista é mais pessoal. E é também mais profunda. Ninguém decifra à primeira vista o mundo misterioso ou feérico que vai aparecendo através de formas, de símbolos, de poemas ou de palavras soltas.

Filia-se essa fase de Estela Campos ao surrealismo, sendo, entretanto, de uma originalidade irrecusável. Que representa ou significa essa explosão de poesia irracional? A pintora é a primeira a confessar que não sabe explicá-la. São composições cabalísticas para ela própria.

[...] De fato, a sua é uma linguagem cifrada, que não deixa de ter o encanto do mistério e do absurdo. Não é o mundo atual o próprio reino do absurdo? Em suas composições abstrato-figurativas, impõe-se soberana a fantasia da artista, que se mostra mais segura dos meios técnicos de sua arte nos desenhos coloridos a tintas sobre papel branco.

Quando estiver mais amadurecida e segura de seu metier, a artista terá muita coisa a dizer. De qualquer modo, sua exposição já foi uma novidade a quebrar a rotina do ano. (Bento, 1958, p. 6).

Mas nem todas as avaliações foram inteiramente positivas. O então jovem crítico José Roberto Teixeira Leite (Rio de Janeiro, Rio de Janeiro, 1930) comenta sobre aquela exposição de Estela Campos em dois textos distintos (Leite, 1958a, 1958b). Em ambos, o teor é semelhante: admirou a composição visual das obras, mas não se agradou daquelas em que a artista fez uso de uma escrita simbólica. Sua crítica dá a entender que a produção de Estela Campos habitava o limiar entre uma concepção modernista de obra como pura visualidade e outra concepção distinta, da obra como informação, conceito ou intertexto:

As cores são o mais importante, nessa obra de valor desigual, em que a pintura cede muita vez lugar a um amálgama entre arte literária e arte visual. É que essa artista, em vários de seus trabalhos, utiliza frases soltas, símbolos químicos etc., que refletiriam um modo pessoal de encarar a obra de arte, já não mais, então, visual, e sim dirigida ora à visão, ora ao puro racional. Algumas obras de Estela Campos, porém, nos dizem que ela é uma pintora, embora ainda não de todo despojada de um mar de fórmulas e de teorias que lhe veio através de livros, em sua maior parte. O seu futuro, como artista plástico, dependendo, por isso, de tal despojamento. Seu caminho é a pura plasticidade de uma obra como "Movimento I" - composição dinâmica, planos que se cortam e não se excluem, cores frias de grande simplicidade e beleza -, não as legendas paranoico-surrealistas de tantos de seus quadros. (Leite, 1958b, p. 24, grifo do autor).

Apesar de todos os pesares, a recepção dessa exposição de Estela Campos parece ter sido bastante positiva. Houve, inclusive, uma homenagem à artista, prestada pela Casa do Pará, no Rio de Janeiro, às vésperas de seu retorno à Belém, quando foi oferecido um coquetel estendido a artistas, jornalistas e outras pessoas da sociedade carioca que quisessem se juntar ao agraciamento (Campofiorito, 1958d).

\section{TERCEIRA EXPOSIÇÃO INDIVIDUAL}

Em 27 de maio de 1959, inaugurava-se a terceira exposição individual de Estela Campos, novamente na Biblioteca e Arquivo Público do Estado do Pará. O catálogo desta mostra, disponível no AHWS, nos informa que a mesma foi realizada 'sob os auspícios da Sociedade Artística Internacional (SAI)', instituição não governamental que parece ter capitaneado o debate cultural em Belém nos anos 1950.

Após o êxito de sua exposição no Rio de Janeiro, Estela Campos, naquele momento, era considerada uma artista "[...] já consagrada, [situada em] plano de destaque no movimento moderno [...]" da arte brasileira, o que motivou grande interesse por sua nova mostra, inaugurada com o "[...] comparecimento das mais destacadas figuras do meio intelectual e artístico [de Belém]” (Inaugurada..., 1959, p. 6).

O catálogo informa os títulos de dezoito obras, divididas entre 'composições' e 'figuras', que nos remetem às duas fases distinguidas por Bento (1958, p. 6) e Campofiorito (1958b, p. 2) no ano anterior. Um dos registros fotográficos publicados em jornal (Figura 4) apresenta, tanto quanto possível, algumas das obras expostas. 
A recepção local parece ter sido novamente positiva, como nos mostra um texto assinado por Joaquim Francisco (Belém, Pará, 1938), jovem intelectual, filho de Inocêncio Machado Coelho, o mesmo que teceu grandes elogios à primeira exposição de Estela Campos em 1957 (Coelho, I., 1957). Ainda assim, é perceptível a inquietação da crítica em suas tentativas de assimilação do trabalho da artista:

Estela Campos volta a expor os seus trabalhos. Pela segunda vez deparamos com um problema de difícil solução: julgar a obra de Estela. Qual o seu sentido, sua finalidade, sua mensagem? A rigor, a incógnita que Estela apresenta é a mesma de todo artista contemporâneo - a busca de uma nova forma para expressão artística. [...] [A obra da artista] se realiza no desespero. Existe nos quadros de Estela essa alucinação e esse absurdo que envolve o artista de nossos dias [...]. Esgotadas as formas habituais de pesquisa estética, o artista de hoje se volta para o inconsciente procurando nele uma fórmula definitiva capaz de retratar a trágica situação do homem em face de um novo mundo. Estela e sua pintura vem colaborar nessa busca de caráter metafísico. Há, contudo, em sua obra (sejamos concordes com F. Paulo Mendes) um lado íntimo e particular que só a psicanálise conseguiria revelar. Toda uma rica vida interior está presente na pintura de Estela, manifestando-se mais claramente nesta segunda exposição. Estela se explica dentro de suas linhas, de suas formas, de suas cores $[\ldots]$.

No momento que ora atravessamos, Estela nos afirma, através de sua pintura, a própria instabilidade de nosso tempo [...]. Sua mensagem, longe de vir carregada de esperança, nos traz a certeza de nossa triste condição. Todavia, o importante é que Estela, como artista verdadeira e autêntica, retrata com absoluta confiança em si e em sua técnica, um estado de coisas cujo fim nem mesmo a arte poderá prever. (Coelho, J., 1959, p. 8).

Essa é, provavelmente, a mostra mencionada por José Rego como motivadora de suas incursões no abstracionismo, situada cerca de três meses antes do surgimento oficial do CAPA e pouco mais de quatro meses antes da exposição do referido artista. Também é a mostra citada por Benedito Nunes, ao comentar, para o cenário paulista, sobre a situação das artes plásticas em Belém no ano de 1959:

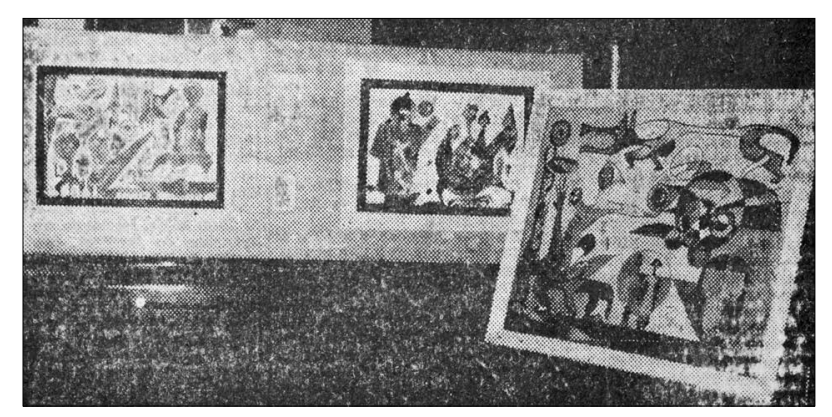

Figura 4. Registro da abertura da exposição de Estela Campos, Biblioteca e Arquivo Público do Estado do Pará, Belém, 1959. Fonte: Inaugurada... (1959, p. 6).

Das exposições de pintura feitas ultimamente destacam-se as levadas a efeito por Ruy Meira, que vem tendendo para a simplificação geométrica das formas, por Paolo Ricci, inventivo, mas ainda na fase da procura técnica, por Benedicto Mello, imerso no tachismo, e por Maria Estela Campos, que une a precisão técnica a uma impressionante imaginação pictórica. (Nunes, 1959, p. 4).

Interessante notar que, escrevendo no final de outubro de 1959, Benedito Nunes já aponta as incursões em vertentes do abstracionismo por Ruy Meira e Benedicto Mello (Belém, Pará, 1926-2004), e não menciona a exposição de José Rego (inaugurada em 17 de outubro de 1959). Por quais motivos, então, essa exposição é tomada pela historiografia como marco inicial do abstracionismo em Belém, enquanto há apenas silêncio sobre as duas mostras de Estela Campos na cidade?

Estela Campos ganhou grande projeção no eixo Rio de Janeiro-São Paulo, promovendo ainda mais duas exposições individuais no Rio de Janeiro (1960 e 1962), participando de três Bienais de São Paulo (1961, 1963 e 1965) e da representação brasileira enviada à II Bienal Americana de Arte (1964), na cidade de Córdoba, Argentina. Apesar disso, seu nome não consta no debate historiográfico sobre a arte do período, assim como suas obras não foram incorporadas a acervos de instituições culturais públicas ou privadas. Caberia investigar quais circunstâncias levaram ao completo esquecimento sobre a artista, em Belém e nas demais cidades brasileiras - tarefa demasiado árdua para a capacidade desta pesquisa.

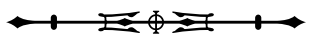




\section{NECESSÁRIA REABILITAÇÃO HISTÓRICA}

$\mathrm{Na}$ contramão dos jornais que acompanharam a primeira exposição de Estela Campos, para os quais esta teria sido a primeira mostra abstracionista em Belém (A Biblioteca..., 1957; Inaugurada..., 1957a), a historiografia da arte local tem consagrado José de Moraes Rego como o primeiro a realizar tal façanha, com sua exposição de outubro de 1959.

Há duas condições importantes a favor do pioneirismo de Rego para o abstracionismo em Belém. A primeira é o fato de ele próprio ter compilado, em livro (Rego, 1986), variados escritos sobre sua trajetória, depois servindo de base para outros estudos. Entre esses textos compilados, está aquele do intelectual Francisco Paulo Mendes (Belém, Pará, 1910-1999), apresentando a mostra, que naquele momento afirmou que "[...] pela primeira vez, em Belém, um pintor inteiramente abstracionista [expunha] seus quadros" (Mendes, 1959 apud Rego, 1986, p. 35). Na ambiguidade interpretativa da frase, o "[...] inteiramente [...]" parece ter sido uma armadilha para os trabalhos posteriores que se utilizaram de tal fonte: de primeiro artista inteiramente abstracionista a expor na cidade, José Rego logo passou a ser considerado o primeiro artista a expor obras abstracionistas em Belém, a despeito das mostras de Estela Campos que lhe precederam.

A segunda condição a favor do pioneirismo de José Rego, que muito provavelmente motivou a afirmação supracitada de Paulo Mendes, é o fato de que, ao menos nas suas duas exposições individuais em Belém, Estela Campos recorreu muitas vezes a uma poética que foi classificada de "[...] abstrato-figurativa [...]" (Exposição..., 1957, p. 7) e "[...] onírica [...]" (Ricci, [1978], p. 306). Nessas obras, é perceptível o aparecimento de determinados seres inventados, ao modo dos surrealistas, como se pode ver nas Figuras 2 e 3.

Ora, o fato de Estela Campos promover em algumas de suas obras diálogo entre abstracionismo e figuração não destitui o caráter modernista pioneiro de suas duas mostras em Belém. E sequer deve eclipsar o fato de que, em quase todas as matérias jornalísticas sobre as exposições da artista, são mencionadas obras suas inteiramente abstracionistas, como se pode ver na Figura 5, de sua primeira exposição, em 1957. Mais do que isso, Estela Campos parecia completamente ciente das vertentes do abstracionismo de cunho geométrico ou construtivo, mas apresentava a busca de soluções inteiramente pessoais, talvez como resultado de sua formação artística com os modernistas portugueses. O diálogo com a poética de certas fases de Almada Negreiros, por exemplo, parece evidente na produção inicial da artista.

Decerto, Estela Campos não poderia ser considerada 'inteiramente abstracionista', como José Rego, já que ela parecia refratária a estagnar seu projeto estético em uma única vertente. "A artista paraense não se filia a nenhuma escola - Não sei o nome que se pode dar a minha pintura, disse. Também tenho certeza que passarei a outros estilos, pois isto é a evolução, acrescentou" (Pintora..., 1958, p. 13). Portanto, Estela Campos já ali estava mais comprometida com uma busca pessoal, surpreendendo positivamente a crítica exercida no Rio de Janeiro em suas três individuais na cidade.

Certamente, sua produção foi tão ou mais importante para a consolidação do abstracionismo em Belém do que a produção dos artistas do CAPA. Primeiro, porque

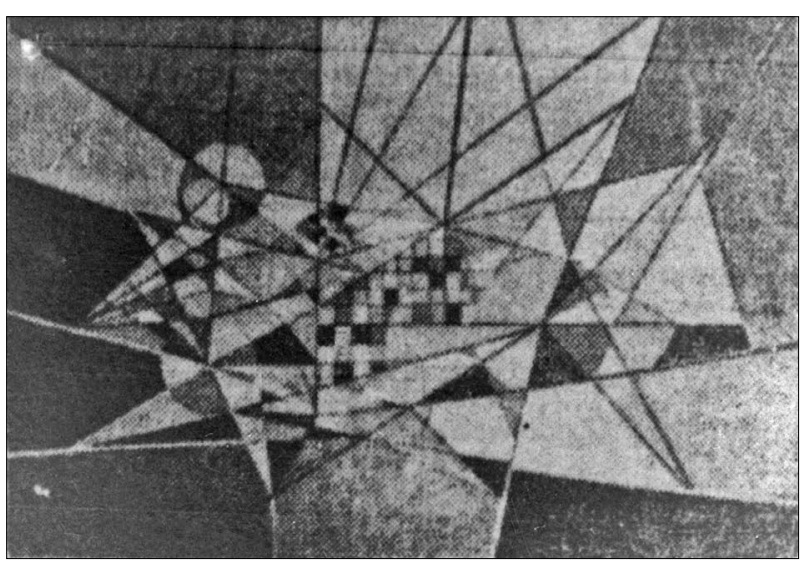

Figura 5. Registro de obra de Miranda Campos, 1957. Fonte: Exposição... (1957, p. 7).

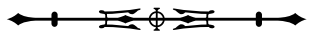


Estela Campos se antecipou aos membros do clube em ao menos dois anos. Lembremos que no final de 1957, após a exposição dela, Ruy Meira inaugurou mostra individual com pinturas ainda de tendência pós-impressionista (Inaugurada..., 1957b). Depois, a autenticidade e o refinamento do projeto estético de Estela Campos indicam uma obra bem mais aprimorada do que a de outros artistas locais.

A pintura abstracionista de Ruy Meira, por exemplo, parece atingir um patamar semelhante somente nos anos 1970, com a fase chamada de "[...] abstracionismo orgânico [...]" por Bitar (1991, p. 50-51). O abstracionismo de José Rego, por outro lado, nem chega a um refinamento igual ao de Estela Campos, já que aquele artista enveredou pela figuração dos anos 1960 em diante. Sabe-se que José Rego, em sua primeira mostra, era pintor iniciante (Rego, 1986, p. 25), o que reforça o fato de seu papel na consolidação do abstracionismo em Belém ter sido superestimado pela historiografia local. Mesmo o texto de Francisco Paulo Mendes sobre a mostra de Rego indica a fragilidade de sua produção naquele momento,

[...] angustiosa procura de equilíbrio criador, que não pode nem podia ainda encontrar, e uma hesitação muito natural que resulta de uma fase inicial, de uma partida, em que o pintor aceita, por vezes, indiferençadamente, diversas tendências. (Mendes, 1959 apud Rego, 1986, p. 35).

É necessário reabilitar o papel desempenhado por Estela Campos para a consolidação do abstracionismo em Belém, até agora encoberto pelo peso concedido a Rego e Ruy Meira na historiografia. As duas mostras da artista foram basilares para a incorporação dessa tendência na cidade. Não sendo informalista nem concretista, mas promovendo uma síntese inteiramente pessoal entre várias correntes, ela abriu caminho para o desenvolvimento das poéticas de vários artistas nas décadas seguintes.

\section{GÊNERO E HISTÓRIA DA ARTE}

Qual ou quais os motivos que levaram ao gradual apagamento de Estela Campos na historiografia da arte local? A primeira hipótese é considerar sua invisibilidade a partir dos estudos sobre gênero. Até que ponto a condição de mulher influenciou seu reconhecimento enquanto artista? Essa é certamente uma questão pouco rastreável, mas a hipótese é inteiramente plausível.

O campo artístico em Belém, naquela altura, era majoritariamente habitado por homens. A historiografia acentuou ainda mais essa predominância masculina, promovendo a gradual invisibilização da trajetória das artistas mulheres. Entre aquelas que atuaram antes e durante os anos 1950, talvez apenas os nomes de Julieta de França (Belém, Pará, 1870-data de falecimento desconhecida) ${ }^{7}$. Antonieta Santos Feio (Belém, Pará, 1897-Santos, São Paulo, 1980) e Carmem Souza (Lisboa, Portugal, 1908-Belém, Pará, 1950) tenham algum reconhecimento local. Depois, nos anos 1960 e 1970, é possível que apenas Dina Oliveira (Belém, Pará, 1951) seja lembrada. Mas há toda uma gama de artistas que o correr dos anos tornou desconhecidas como Estela Campos (o que, é claro, também ocorreu com artistas homens, restando investigar se nas mesmas proporções): Christina Capper Alves de Souza ${ }^{9}$, Dahlia Déa ${ }^{10}$, Betty Veiga Santos (Belém, Pará, 1921-2015)11, Concy Cutrim (Benevides, Pará, 1929), Maria Madalena (Belém, Pará, 1949), Lília Chaves (Belém, Pará, 1951), entre outras. Somente a partir dos anos 1980 é que se percebe maior equilíbrio entre o reconhecimento de artistas homens e mulheres.

As artistas mulheres estão presentes em grande número na arte brasileira, ao menos no século 20 , e sua

\footnotetext{
A seu respeito, bem como sobre as dificuldades enfrentadas em sua trajetória, conferir Simioni (2008, p. 246-260).

O trabalho mais substancial sobre a artista pode ser conferido em Fernandes (2009).

9 Data de nascimento desconhecida. Atuante na transição entre os séculos 19 e 20.

Data de nascimento desconhecida. Atuante nas décadas de 1930 e 1940.

11 Sobre a artista, conferir Farias e Netto (2015).
}

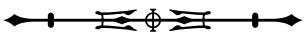


contribuição é, em muitos casos, tão ou mais relevante em comparação com a de artistas homens coetâneos (Amaral, 1993). É possível que essa sólida presença feminina se deva ao fato de que, no Brasil (dentro da tradição ibérica), as artes tenham sido socialmente entendidas como atividades próprias das mulheres - um tipo de complementação da educação feminina de membros das classes abastadas (Amaral, 1993, p. 17-18).

Entretanto, apesar de o aprendizado da pintura, da música ou de outras atividades constituir uma aproximação das mulheres brasileiras ao campo artístico, tal proximidade não eliminou as ideias de inferiorização feminina difundidas à época. Sobre as mulheres, pesou o rótulo de "[...] amadoras [...]" (Simioni, 2008)12, de "[...] moças prendadas [...]" (Zaccara, 2017), dificilmente reconhecidas como profissionais, tal qual os artistas homens.

fato de outra artista mulher, Antonieta Santos Feio, ter apresentado largo reconhecimento em Belém, nas décadas de 1930 a 1950, talvez relativize o peso da questão de gênero no esquecimento público da artista Estela Campos. Antonieta Feio participou de várias das mostras competitivas promovidas em Belém, teve obras encomendadas ou adquiridas por instituições públicas, tem sido frequentemente mencionada na historiografia da arte desta cidade, entre outros fatores.

O êxito de Antonieta Feio em Belém pode indicar que o campo artístico na cidade esteve receptivo, naquele período, para artistas mulheres - havendo a possibilidade remota da existência de um retraimento a partir de meados dos anos 1950. Ao se comparar a produção das duas artistas, porém, as diferenças são extremas: a obra de Antonieta Feio está vinculada à pintura figurativa de cunho acadêmico. Tal fato nos remete à ideia de que o principal fator para o esquecimento que pesou sobre Estela Campos tenha sido o provincianismo do campo artístico diante do caráter progressista e cosmopolita de sua obra - hipótese que comentarei adiante.
Entretanto, assimilando as lições que os estudos sobre gênero têm dado à história da arte, cabe não minimizar a influência que uma sociedade imersa em hierarquia de gênero, de estrutura nitidamente sexista (o Brasil dos anos 1950 e 1960), pode ter exercido sobre a trajetória de Estela Campos.

\section{COSMOPOLITISMO E PROVINCIANISMO}

A segunda hipótese com a qual podemos trabalhar é a da inadequação da obra de Estela Campos em relação ao campo artístico em Belém. Como se viu em suas exposições individuais, a sua produção era cosmopolita e progressista, posto que dialogava com o que havia de mais 'vanguardista' nos circuitos artísticos internacionais: os abstracionismos e as alternativas ao esgotamento do mesmo.

Na segunda metade dos anos 1950, a pop art, o novo realismo e as demais rupturas conceitualistas internacionais estavam ainda em germinação. A obra de Estela Campos não parece ter tido a mesma 'contemporaneidade' desses movimentos. Mas não podemos esquecer que, entre 1957 e 1959, Hélio Oiticica (Rio de Janeiro, Rio de Janeiro, 19371980), Lygia Clark (Belo Horizonte, Minas Gerais, 1920-Rio de Janeiro, Rio de Janeiro, 1988) e outros artistas brasileiros dos anos 1960, hoje consagrados, eram, em sua maioria, pintores vinculados ao concretismo. Talvez tenha faltado um solo propício para o desenvolvimento artístico de Estela Campos.

Este solo não poderia ser Belém. Diferentemente das cidades do Rio de Janeiro ou de São Paulo, Belém era pouco cosmopolita, chegando mesmo a ser provinciana no que dizia respeito ao campo artístico. Uma matéria em jornal carioca, veiculada no período da primeira exposição de Estela Campos no Rio de Janeiro, nos deixa entrever duas coisas: o provincianismo de Belém no que dizia respeito às artes plásticas; e, por outro lado, o início de uma efervescência cultural 'modernista', que a própria artista integrou e mesmo fomentou:

\footnotetext{
12 Especialmente o capítulo 1.
}

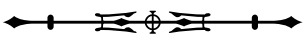


Estela Campos, falando do progresso artístico do Pará, tem uma queixa: - Em Belém, não há, praticamente, movimento artístico. Todos trabalham isoladamente, disse. Gostaria de contribuir para uma união entre os artistas, para que esse progresso fosse mais rápido.

A aceitação da arquitetura moderna pelo povo de Belém, e o fato de o Governo lhe haver concedido uma bolsa [para expor no Rio de Janeiro], são os exemplos citados pela pintora para mostrar o interesse que o povo tem pela arte moderna. (Pintora..., 1958, p. 13).

Não obstante, no início dos anos 1960 ela parece abandonar o tom otimista. Nesse sentido, é sintomática a visão da cidade que Estela Campos formulou em suas correspondências para a Bienal de São Paulo, em que parece evidente que sua permanência em Belém era circunstancial, motivada por problemas de ordem familiar, e que essa permanência dificultava seu desenvolvimento artístico.

Há sete meses que me encontro em Belém do Pará para onde tive que embarcar, urgentemente, em consequência da morte de minha mãe e agravamento profundo do estado de saúde do meu pai. Lamentavelmente só eu posso atender aqui às diversas injunções que surgem, pois meus irmãos residem na Europa e não podem ajudar-me. Desta forma, fiquei no Rio sem ter quem receba meus trabalhos que foram expostos na VII Bienal, quando forem remetidos de volta, aos artistas expositores. Acontece que não os desejo em Belém visto que, além de serem grandes e quebráveis, não tenho o menor interesse em tê-los nestas paragens ${ }^{13}$.

Os problemas comentados passavam por extravio de correspondências, dificuldade na chegada de informações, inexistência de fichas de inscrição da Bienal de São Paulo (e de outros eventos nacionais, presume-se) nas instituições culturais locais, dificuldades para remeter obras e, até mesmo, ausência de materiais especializados no mercado local ${ }^{14}$. Em tudo pesava a ideia de um "[...] impossível da distância $[\ldots]^{\prime 15}$.
A relação entre Estela Campos e Belém, vista a partir das esparsas fontes que nos restam, parece ter sido complexa e problemática. Em suas correspondências com a Bienal de São Paulo, demonstra pouca radicação na cidade: em todas as fichas de inscrição submetidas (edições de 1953, 1961, 1963 e 1965), sua residência consta no Rio de Janeiro; nas cartas remetidas à instituição, sua residência em Belém parece ser sempre provisória e circunstancial.

Por outro lado, para o campo artístico da cidade do Rio de Janeiro, Estela Campos é mostrada quase sempre como uma "[...] artista paraense [...]" (Bento, 1958, p. 6; Campofiorito, 1958a, p. 7; Leite, 1958a, p. 10; Moraes, 1958, p. 6; Pintora..., 1958, p. 13). Haveria aí a adoção pela artista de duas estratégias distintas, adequadas a momentos e lugares diferentes? Ou a progressiva desvinculação de Estela Campos (em relação ao panorama cultural de Belém) é mesmo sintoma e consequência do provincianismo daquele campo artístico?

O provincianismo a que me refiro pode ser entendido como "[...] uma atitude de submissão a uma hierarquia de valores culturais imposta externamente. Não é [exclusivamente] produto da história colonialista nem meramente função da localização geográfica" (Smith, 1975, p. 30). O campo artístico em Belém pode ser tomado por provinciano principalmente pela adoção de ideias e de práticas artísticas estrangeiras e já defasadas - ato que Souza (2010, p. 30) chama com sagacidade de "[...] coprofagia cultural [...]" -, assim como pela busca de uma identidade local calcada na construção de regionalismos.

É evidente que, no caso de Estela Campos, não se deve descartar a ideia de que a adoção de práticas abstracionistas tenha sido, por si só, uma atitude provinciana, de submissão a uma moda estrangeira. Mas o projeto estético desenvolvido pela artista, rastreável na

\footnotetext{
13 Carta de Estela Campos à Bienal de São Paulo, datada de 11 jan. 1964, p. 1. AHWS, Fundação Bienal de São Paulo, São Paulo.

${ }_{14}$ Conferir as cartas de Estela Campos à Bienal de São Paulo datadas de: 27 nov. 1961; 5 nov. 1963; 2 abr. 1965; e 1 jun. 1965. AHWS, Fundação Bienal de São Paulo, São Paulo.

15 Carta de Estela Campos à Bienal de São Paulo, sem data, recebida em 22 abr. 1965, p. 1. AHWS, Fundação Bienal de São Paulo, São Paulo.
}

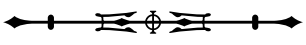


documentação existente (embora nenhuma obra sua tenha sido localizada), indica que sua produção não se submetia às correntes vigentes, mas, antes, buscava estabelecer parâmetros estéticos e teóricos próprios, em um diálogo horizontal com essas correntes.

O tema do cosmopolitismo/provincianismo na relação entre campos artísticos já é discutido há algum tempo, formulado em termos de centro/periferia ${ }^{16}$. Recentemente, recoloca-se o debate em termos de zonas de contato e em relações menos antagônicas e eurocentradas, atentando-se cada vez mais para as muitas conexões até então menosprezadas, e observando-se o provincianismo como condição da própria colonialidade. Duas tentativas, a partir de Belém, podem ser vistas em Figueiredo e Rodrigues (2017) e em Vieira Costa (2015).

No caso de Estela Campos, o provincianismo de Belém é ainda uma hipótese. É sabido que outros artistas estrangeiros tiveram relativo êxito em suas estadias na cidade, entre os anos 1940 e 1960, como Raul Deveza (Rio de Janeiro, Rio de Janeiro, 1891-Manaus, Amazonas, 1952), Armando Balloni (Itália, 1901-São Paulo, São Paulo, 1969) e Tadashi Kaminagai (Hiroshima, Japão, 1899-Paris, França, 1982) (Ricci, [1978], p. 282-299). O fato de serem artistas homens reforça a hipótese de que o esquecimento de Estela Campos seja uma questão de papel de gênero na história da arte. Porém, outra semelhança é o fato de serem todos artistas figurativos - o que reforça a ideia de que Estela Campos tenha sido preterida por conta de sua obra ser progressista demais para Belém.

No entanto, como vimos, as narrativas construídas reforçam o papel de outros dois artistas homens (José de Moraes Rego e Ruy Meira) no advento do abstracionismo no campo artístico local, o que nos devolve ao debate sobre gênero. Os contornos de provincianismo e sexismo me parecem cada vez mais complexos e interligados: em Belém, nos anos 1950, é plausível considerar que um aspecto alimentava o outro, e que o ocultamento do papel de Estela Campos no campo artístico da cidade tenha sido produzido por ambos.

A situação provinciana parece ter sido semelhante em outra grande cidade amazônica, Manaus, tal como percebida por Márcio Souza até os anos 1970. A comparação entre as trajetórias de Estela Campos e de Hahnemann Bacelar (Manaus, Amazonas, 1948-Belém, Pará, 1971) (Souza, 2010, p. 21-27), por exemplo, pode ser muito pertinente, deslocando a condição de gênero para questões de classe social e de comportamento.

As estruturas de colonialidade que condicionaram tal provincianismo em Belém não podem ser discutidas no espaço deste texto. As consequências dessa colonialidade, no entanto, produziram a sensação de isolamento geográfico e cultural, experimentada por artistas na cidade durante a primeira metade do século $X X$, após a crise da economia gomífera, sensação que parece ter sido revertida apenas nos anos 197017.

Um intelectual como Benedito Nunes chega mesmo a falar do "[...] insulamento [...]" das atividades culturais surgidas na cidade, fadadas a serem como "[...] irrupções efêmeras $[\ldots]$, pequenas ilhas que se incrustam, como organismos estranhos, no meio de uma sociedade que não está preparada para contê-las" (Nunes, 1959, p. 4, grifo do autor).

A colonialidade e o isolamento (real ou imaginado) constituíram um campo artístico pouco sintonizado com as discussões artísticas internacionais, um campo em que prevaleciam questões peculiares e onde predominavam as correntes pós-impressionistas na pintura. Não à toa, o abstracionismo teve o pontapé inicial dado por uma personagem como Estela Campos: artista formada no trânsito

16 Conferir, além de Smith (1975), o texto de Castelnuovo e Ginzburg (1991).

17 Esse tema - o isolamento geográfico e cultural - aparece em fontes diversas, entre as quais indico especialmente Ricci ([1978], p. 336 e 351), Sobral (2002, p. 32-33) e Vieira Costa (2016, p. 907).

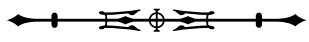


por outras cidades diversas. E não à toa, houve um rechaço às primeiras obras e exposições abstracionistas em Belém, como se pode intuir a partir de Ricci ([1978], p. 307-309).

Essa inadequação da obra de Estela Campos, radical demais para um campo artístico até então incapaz de efetivos diálogos nacionais e internacionais, talvez justifique sua ausência nas duas edições do Salão de Artes Plásticas promovidas pela Universidade do Pará (atual Universidade Federal do Pará - UFPA), em 1963 e 1965. As datas coincidem com suas duas últimas participações na Bienal de São Paulo. Causa espanto o contraste entre tamanho esforço para participar de um evento distante, e nenhum para participar da principal mostra regional. Outra possibilidade, não menos curiosa, é a de que sua produção tenha tido êxito em São Paulo, mas que tenha sido recusada pelas comissões de seleção em Belém, o que ratificaria o provincianismo apontado nesta última.

Ao contrário do que suas fichas de inscrição na Bienal de São Paulo sugerem, Estela Campos não parecia estar definitivamente fixada no Rio de Janeiro naquele momento, como atestam suas cartas à Bienal de São Paulo e a publicação de seu livro "Kalta-ítsia" pela Universidade do Pará, em 1964. A artista parecia orientar sua obra para o eixo RJ-SP, talvez sentindo o 'lá' como um solo mais propício que o 'aqui'.

\section{O PESO DO LOCALISMO}

Por fim, a respeito da invisibilidade de Estela Campos, há uma terceira hipótese que necessita ser discutida. Diferentemente das condições sexistas e provincianas, que estariam vinculadas ao contexto histórico em que a artista estava produzindo, essa terceira condição não é restrita àquela década, trazendo seus desdobramentos até o presente. Pode-se falar de um 'localismo' no campo artístico em Belém, e de seu possível peso agindo para o apagamento de Estela Campos nas narrativas sobre o abstracionismo na cidade.

O que constitui este localismo? Uma cosmovisão centrada em fronteiras geopolíticas, incapaz de perceber os fluxos e as ligações estabelecidas dentro, entre e/ou para além dessas fronteiras. No caso do campo de estudos que este trabalho integra, a consequência óbvia é a construção de uma história da arte 'em' Belém (ou 'no' Pará), em vez de uma história da arte 'a partir de' Belém ou 'do' Pará. Tal localismo tenta encaixar a complexidade da produção artística dentro de fronteiras que não lhe correspondem, minimizando ou desconsiderando as relações estabelecidas entre os diversos grupos sociais (distintos no tempo e/ou no espaço que habitam) que fazem parte do mundo da arte.

A proposição das chamadas connected histories tem atentado para tal conjuntura: as historiografias nacionais, a história cultural ou etno-história e a micro-história muitas vezes têm contribuído para descontextualizar os seus objetos de estudo, apagando suas conexões (inter)nacionais e (inter)continentais, em prol de um discurso baseado nas fronteiras, mais do que em seus atravessamentos (Gruzinski, 2003).

Essa cosmovisão localista pode ter condicionado a percepção constituída por muitos críticos e artistas sobre o trabalho de Estela Campos, entre os que atuavam em Belém no momento em que ela produzia e expunha na cidade. Sendo uma artista de formação portuguesa e de circulação carioca/paulista, desconsiderar sua relevância para o abstracionismo em Belém pode ter sido uma ideia bastante atraente, já que ela não se enquadrava facilmente no rótulo de 'artista paraense'. Tal hipótese explicaria o porquê de Estela Campos, por exemplo, ser adjetivada como "[...] pintora brasileira [...]" em uma das notas jornalísticas publicadas em Belém sobre seu trabalho (Exposição..., 1957, p. 7).

Porém, mais importante ainda é o fato de que esta cosmovisão localista pode ter alimentado as abordagens metodológicas dos trabalhos historiográficos sobre abstracionismo em Belém, desenvolvidos nas últimas décadas. É sintomático que, em um artigo de Farias e Ribeiro (2010), Estela Campos surja em uma nota de rodapé, a partir da leitura de Ricci ([1978]), e que seja mencionada como personagem que "[...] necessita ser investigada [...]", mas, apesar disso, seja desde logo proscrita como "[...] não 
tão vinculada ao campo cultural plástico do Pará" (Farias e Ribeiro, 2010, p. 344). Assim, de Ricci ([1978]) a Rego (1986) e Sobral (2002), além de outros trabalhos derivados destes, Estela Campos não conseguiu ultrapassar a condição de 'nota de rodapé' para a história local, ainda carecendo de esforços substanciais de pesquisa - daí a importância de localizar e de disponibilizar novas fontes sobre sua produção, estimulando o debate sobre sua presença no campo artístico em Belém e em outras cidades brasileiras.

\section{CONSIDERAÇÕES FINAIS}

É mais que necessária a reabilitação da obra de Estela Campos para a historiografia da arte paraense. Seu papel foi fundamental para a consolidação do abstracionismo no campo artístico em Belém, apesar de ter sido protelado ou mesmo menosprezado em grande parte dos estudos que se dedicaram ao assunto no decorrer dessas seis décadas.

Deve-se investigar a possibilidade de que esta invisibilidade pública tenha sido estrutural ou até mesmo intencional, motivada por crenças e práticas sexistas, provincianas e/ou localistas dos agentes do campo artístico, e de que invisibilidade semelhante tenha sido impingida a outros artistas, por seu gênero, pelas características progressistas de sua obra e/ou por sua inadequação às fronteiras de uma cosmovisão aferrada à ideia de local. Outros aspectos não são menos importantes: condições econômicas, geográficas, de repertório cultural etc.

Tais hipóteses somente podem ser testadas a partir da multiplicação dos estudos de caso (especialmente sobre legitimação e projeção de artistas) e das análises comparativas entre os mesmos, sem desconsiderar os vínculos e as relações existentes entre pessoas, grupos sociais e campos artísticos distintos no tempo e/ou no espaço. A tarefa parece árdua, mas talvez nos ajude a compreender um pouco mais sobre como temos construído esses objetos (a 'arte paraense', a 'arte brasileira' e suas respectivas histórias) e que esforço seria necessário para reconstruí-los de modo mais preciso e crítico.
A obra de Estela Campos também é de fundamental interesse para os estudos sobre arte brasileira nas décadas de 1950 e 1960, pela aparente qualidade do projeto estético e artístico que desenvolveu. Tal projeto, inteiramente pessoal e autêntico, se colocou no debate entre figuração e abstração, assim como na querela entre vertentes informalistas e construtivas do abstracionismo, tão importante para a historiografia da arte brasileira que se debruça sobre esse período.

Sendo insuficiente o espaço deste artigo, os registros existentes de suas obras serão objeto de futuras investidas críticas, no sentido de uma 'cripto-história artística' (Serrão, 2001). Da mesma maneira, seu projeto literário também necessita de um esforço analítico semelhante, feito em conjunto com a investigação de sua atuação nas artes plásticas.

\section{AGRADECIMENTOS}

O presente trabalho foi realizado com apoio do Conselho Nacional de Desenvolvimento Científico e Tecnológico (CNPq) (processo n. 305250/2016-7), por meio de bolsa de doutorado sanduíche no país concedida de março a agosto de 2017 para estada em São Paulo, sob orientação do Prof. Dr. Aldrin Moura de Figueiredo (Instituto de Filosofia e Ciências Humanas da Universidade Federal do Pará - IFCH/UFPA) e coorientação do Prof. Dr. Tadeu Chiarelli (Escola de Comunicações e Artes da Universidade de São Paulo - ECA/USP).

\section{REFERÊNCIAS}

A BIBLIOTECA em agosto. A Província do Pará, Belém, 10 set. 1957. Caderno 1, p. 3.

AMARAL, Aracy. Brasil: a mulher nas artes. In: AMARAL, Aracy A.; HERKENHOFF, Paulo. Ultramodern: the art of contemporary Brazil. Washington: The National Museum of Women in the Arts, 1993. p. 17-32.

A PROVÍNCIA DO PARÁ, Belém, 22 ago. 1957. Caderno 2, p. 6.

AYALA, Walmir. Dicionário de pintores brasileiros. [Rio de Janeiro]: Spala, 1986. v. 2.

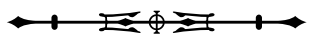


BENTO, Antônio. Estela Campos. Diário Carioca, 20 set. 1958. Caderno 1, p. 6.

BITAR, Rosana. Arte e transcendência: a obra de Ruy Meira. Belém: Estacon, 1991.

BRAGA, Júnia de Barros. O Clube de Artes Plásticas da Amazônia: a experimentação abstrata e as transformações na pintura de seus artistas. 2003. 205 f. Dissertação (Mestrado em Artes Visuais) Escola de Belas Artes, Universidade Federal do Rio de Janeiro, Rio de Janeiro, 2003.

CAMPOFIORITO, Quirino. Pintora do Pará vai expor no Rio. O Jornal, Rio de Janeiro, 17 ago. 1958a. Caderno 1, p. 7.

CAMPOFIORITO, Quirino. Estela Campos. O Jornal, Rio de Janeiro, 20 set. 1958b. Caderno 2, p. 2.

CAMPOFIORITO, Quirino. Duas pintoras. O Jornal, Rio de Janeiro, 23 set. 1958c. Caderno 2, p. 3.

CAMPOFIORITO, Quirino. Homenagem a Estela Campos. O Jornal, Rio de Janeiro, 8 out. 1958d. Caderno 2, p. 3.

CAMPOS, Estela. Kalta-ítsia. Belém: Universidade do Pará, 1964.

CASTELNUOVO, Enrico; GINZBURG, Carlo. História da arte italiana. In: GINZBURG, Carlo. A micro-história e outros ensaios. Tradução de António Narino. Lisboa: Difel; Rio de Janeiro: Bertrand Brasil, 1991. p. 5-117. (Memória e Sociedade).

CAVALCANTI, Carlos. Dicionário brasileiro de artistas plásticos. Brasília: Instituto Nacional do Livro, 1973. v. 1.

COELHO, Inocêncio Machado. Nota sobre a escultora e pintora Miranda Campos. A Província do Pará, Belém, 25 ago. 1957. Caderno 1, p. 8.

COELHO, Joaquim Francisco. Da pintura de Estela Campos. A Província do Pará, Belém, 31 maio 1959. Caderno 1, p. 8.

COUTO, Maria de Fátima Morethy. Por uma vanguarda nacional: a crítica brasileira em busca de uma identidade artística (1940-1960). Campinas: Unicamp, 2004.

ESTELA Campos. In: ENCICLOPÉDIA ITAÚ CULTURAL DE ARTE E CULTURA BRASILEIRAS. São Paulo: Itaú Cultural, 2017. Disponível em: <http://enciclopedia.itaucultural.org.br/ pessoa22996/estela-campos >. Acesso em: 27 ago. 2017.

EXPOSIÇÃO de pintura moderna na Biblioteca Pública, hoje. Folha do Norte, Belém, 21 ago. 1957. Caderno 1, p. 7.

FARIAS, Edison; NETTO, Joaquim. Os últimos suspiros da pintura acadêmica em Belém do Pará: a herança Betty Veiga Santos. In: ENCONTRO DA ASSOCIAÇÃO NACIONAL DE PESQUISADORES EM ARTES PLÁSTICAS, 24., 2015, Santa Maria (RS). Anais... Santa Maria (RS): ANPAP/UFSM, 2015. p. 2016-2031.
FARIAS, Edison; RIBEIRO, Ilton. Bienal (somente duas): a arrancada cultural de uma universidade nortista sem tradição nas artes plásticas. In: FÓRUM BIENAL DE PESQUISA EM ARTES, 5., 2010, Belém (PA). Anais... Belém (PA): UFPA, 2010. p. 334-346.

FARIAS, Edison. Calor, chuva, tela e canivete: a pintura no tempo do modernismo em Belém. 2003. 185 f. Tese (Doutorado em Artes Visuais) - Escola de Comunicações e Artes, Universidade de São Paulo, São Paulo, 2003.

FERNANDES, Caroline. O moderno em aberto: o mundo das artes em Belém do Pará e a pintura de Antonieta Santos Feio. 2009. 186 f. Dissertação (Mestrado em História) - Centro de Estudos Gerais, Universidade Federal Fluminense, Niterói (RJ), 2009.

FIGUEIREDO, Aldrin; RODRIGUES, Silvio. Onde estava a periferia da arte? Circulação e recepção de cópias de pintura europeia na Amazônia no século XIX. Revista Tempo, Niterói, v. 23, n. 3, p. 589-608, set.-dez. 2017. DOI: http://dx.doi.org/10.1590/tem$1980-542 \times 2017 v 230310$

FREQUÊNCIA à Biblioteca. A Província do Pará, Belém, 10 out. 1957. Caderno 2, p. 1.

FUNDAÇÃO BIBLIOTECA NACIONAL (FBN). Hemeroteca digital. Rio de Janeiro: FBN, 2017. Disponível em: < http://bndigital. bn.gov.br/hemeroteca-digital/>. Acesso em: 19 set. 2017.

FUNDAÇÃO BIENAL DE SÃO PAULO. VIII Bienal Internacional de São Paulo: catálogo geral. São Paulo, 1965.

FUNDAÇÃO BIENAL DE SÃO PAULO. VII Bienal Internacional de São Paulo: catálogo geral. São Paulo, 1963.

FUNDAÇÃO BIENAL DE SÃO PAULO. VI Bienal Internacional de São Paulo: catálogo geral. São Paulo, 1961.

GRUZINSKI, Serge. O historiador, o macaco e a centaura: a "história cultural" no novo milênio. Estudos Avançados, São Paulo, v. 17, n. 49, p. 321-342, set.-dez. 2003. DOI: http://dx.doi. org/10.1590/S0103-40142003000300020.

II BIENAL de São Paulo: aviso aos artistas do Rio. Correio da Manhã, Rio de Janeiro, 20 ago. 1953. p. 11.

INAUGURADA a exposição de Estela Campos. A Província do Pará, Belém, 28 maio 1959. Caderno 2, p. 6.

INAUGURADA ontem a exposição de arte abstrata da pintora Miranda Campos. A Província do Pará, Belém, 22 ago. 1957a. Caderno 2, p. 6.

INAUGURADA ontem a exposição de Rui Meira. A Província do Pará, Belém, 1 dez. 1957b. Caderno 3, p. 10.

LEITE, José Roberto Teixeira. Estela Campos na São José: último dia. Diário de Notícias, Rio de Janeiro, 23 set. 1958a. Caderno 1, p. 10

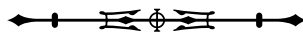


LEITE, José Roberto Teixeira. Roteiro das exposições. Revista da Semana, Rio de Janeiro, ano 58, n. 40, 4 out. 1958b. p. 24.

MAURÍCIO, Jayme. Itinerário das artes plásticas. Correio da Manhã, Rio de Janeiro, 14 ago. 1960. Caderno 2, n. 20671, p. 2.

MENDES, Francisco Paulo. Texto de apresentação. In: REGO, José de Moraes. Exposição de pintura abstrata. Catálogo de exposição. Belém, Sede Social do Clube do Remo, 17 a 30 out. 1959. 2 p.

MOKARZEL, Marisa. Panorama da pintura no Pará: exposição de acervo. Catálogo de exposição realizada de 14 a 30 jun. 2000. Belém: SECULT/SIM, 2000.

MORAES, Eneida de. Encontro Matinal. Diário de Notícias, Rio de Janeiro, 18 set. 1958. Caderno 2, p. 6.

NUNES, Benedito. Panorama cultural: 1959. Suplemento Literário, São Paulo, 31 out. 1959. Caderno 1, p. 4.

PINHEIRO, Vitor Sales. Nota biográfica. Asas da Palavra, Belém, v. 12, n. 25, p. 63, jun. 2009.

PINTORA paraense anuncia que a arte moderna está tomando conta de Belém. Jornal do Brasil, Rio de Janeiro, 19 set. 1958. Caderno 1, p. 13.

PONTUAL, Roberto. Dicionário das artes plásticas no Brasil. Rio de Janeiro: Civilização Brasileira, 1969.

REGO, José de Moraes. 40 anos de arte. Belém: José de Moraes Rego, 1986.

REGO, José de Moraes. Colonialismo cultural e provincialismo. O Estado do Pará, Belém, 15 dez. 1979. Caderno 2, p. 2.

REGO, José de Moraes. A criança diante da vida na pintura ingênua de Rego. O Liberal, Belém, 28 mar. 1976. Caderno 2, p. 4.

RICCI, Paolo. As artes plásticas no Pará. Relatório de pesquisa inédita depositado no CEDOC/Funarte. [1978]. 3 v., 412 f.
SERRÃO, Vítor. A cripto-história de arte: análise de obras de arte inexistentes. Lisboa: Livros Horizonte, 2001.

SIMIONI, Ana Paula Cavalcanti. Profissão artista: pintoras e escultoras acadêmicas brasileiras. São Paulo: Edusp/Fapesp, 2008.

SMITH, Terry. O problema do provincianismo. Malasartes, Rio de Janeiro, n. 1, p. 30-32, set.-nov. 1975.

SOBRAL, Acácio. Momentos iniciais do abstracionismo no Pará. Belém: IAP, 2002.

SOUZA, Márcio. A expressão amazonense: do colonialismo ao neocolonialismo. 3. ed. Manaus: Valer, 2010.

UMA EXPOSIÇÃO de arte abstrata. A Província do Pará, Belém, 20 ago. 1957. Caderno 2, p. 6.

VIEIRA COSTA, Gil. Artista Estela Campos: fontes disponíveis (1957-1965). In: ENCONTRO DA ASSOCIAÇÃO NACIONAL DE PESQUISADORES EM ARTES PLÁSTICAS, 27., 2018, São Paulo (SP). Anais... São Paulo: ANPAP/UNESP, 2018. No prelo.

VIEIRA COSTA, Gil. Contemporaneidade artística em Belém e a Bienal Amazônica de Artes Visuais (1972). In: ENCONTRO DA ASSOCIAÇÃO NACIONAL DE PESQUISADORES EM ARTES PLÁSTICAS, 25., 2016, Porto Alegre (RS). Anais... Porto Alegre: ANPAP/UFRGS, 2016. p. 898-913.

VIEIRA COSTA, Gil. Belém, neocolonialismo, história e historiografia da arte contemporânea brasileira. Arte \& Ensaios, Rio de Janeiro, ano 21, n. 29, p. 76-85, jun. 2015.

VILLAS BÔAS, Gláucia. Concretismo. In: BARCINSKI, Fabiana. Sobre a arte brasileira: da pré-história aos anos 1960. São Paulo: Martins Fontes/SESC, 2014. p. 264-293.

ZACCARA, Madalena. Mulheres artistas em Pernambuco: uma introdução. In: ZACCARA, Madalena (Org.). De sinhá prendada a artista visual: os caminhos da mulher artista em Pernambuco. Recife: Madalena Zaccara, 2017. p. 16-48.

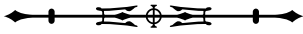


